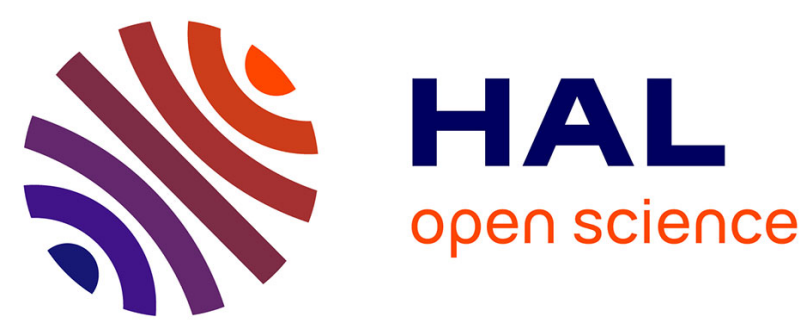

\title{
French Alpine Foreland Holocene Paleoseismicity Revealed by Coeval Mass Wasting Deposits in Glacial Lakes
}

Emmanuel Chapron, Anaëlle Simonneau, Grégoire Ledoux, Fabien Arnaud, Patrick Lajeunesse, Patrick Albéric

\section{To cite this version:}

Emmanuel Chapron, Anaëlle Simonneau, Grégoire Ledoux, Fabien Arnaud, Patrick Lajeunesse, et al.. French Alpine Foreland Holocene Paleoseismicity Revealed by Coeval Mass Wasting Deposits in Glacial Lakes. Submarine Mass Movements and their Consequences, V, pp.341-349, 2015, 978-3-31920978-4. 10.1007/978-3-319-20979-1_34.insu-01240867

\section{HAL Id: insu-01240867 https://hal-insu.archives-ouvertes.fr/insu-01240867}

Submitted on 19 Jan 2017

HAL is a multi-disciplinary open access archive for the deposit and dissemination of scientific research documents, whether they are published or not. The documents may come from teaching and research institutions in France or abroad, or from public or private research centers.
L'archive ouverte pluridisciplinaire HAL, est destinée au dépôt et à la diffusion de documents scientifiques de niveau recherche, publiés ou non, émanant des établissements d'enseignement et de recherche français ou étrangers, des laboratoires publics ou privés. 


\title{
Chapter 34 \\ French Alpine Foreland Holocene \\ Paleoseismicity Revealed by Coeval Mass Wasting Deposits in Glacial Lakes
}

\author{
Emmanuel Chapron, Anaëlle Simonneau, Grégoire Ledoux, \\ Fabien Arnaud, Patrick Lajeunesse, and Patrick Albéric
}

\begin{abstract}
The French alpine foreland area has been struck by several earthquakes with magnitudes above 5 on Richter scale in recent history. In this paper we document the regional impact of historical and Holocene earthquakes based on the identification of mass wasting deposits in glacial lakes at different settings. Lake Le Bourget and Lake Paladru are situated at low elevations (respectively $231 \mathrm{~m}-492 \mathrm{~m}$ ) and Lake Blanc Huez is located at $2500 \mathrm{~m}$ altitude. Through the integration of high-resolution acoustic profiles and accurately dated sediment samples from cores, recent coeval mass wasting deposits in each lake were correlated with nearby historical earthquakes, whereas coeval mass wasting deposits around $5200 \mathrm{cal} \mathrm{BP}$ and $9550 \mathrm{cal} \mathrm{BP}$ in these three lakes were correlated to regional earthquakes events.
\end{abstract}

\footnotetext{
E. Chapron $(\bowtie)$

GEODE UMR 5602 CNRS-Université Toulouse Jean Jaurès, 5 Allée A. Machado, 31058 Toulouse cedex 9, France

Institut des Sciences de la Terre d'Orléans, UMR 7327 CNRS-Université d'Orléans, 1A rue de la Férollerie, 45071 Orléans cedex 2, France e-mail: emmanuel.chapron@univ-tlse2.fr
A. Simonneau • P. Albéric
Institut des Sciences de la Terre d'Orléans, UMR 7327 CNRS-Université d'Orléans, 1A rue de la Férollerie, 45071 Orléans cedex 2, France
G. Ledoux $\bullet$ P. Lajeunesse
Centre d'études nordiques, Département de Géographie, Université Laval, Québec, QC G1VOA6, Canada
F. Arnaud
EDYTEM UMR 5204 CNRS-Université de Savoie, 73376 Le Bourget du Lac, France 


\subsection{General Setting and Data}

The French Alpine foreland area (Fig. 34.1) was covered by ice during the last glaciation. Following deglaciation, thick lacustrine sequences were deposited in numerous over-deepened basins (Van Rensbergen et al. 1999). Over the last 300 years, several earthquakes with magnitudes above 5 on Richter scale struck this part of the alpine range (Nomade et al. 2005). Seismic activity on active faults (Thouvenot et al. 2003) in this populated and industrial region is a hazard because

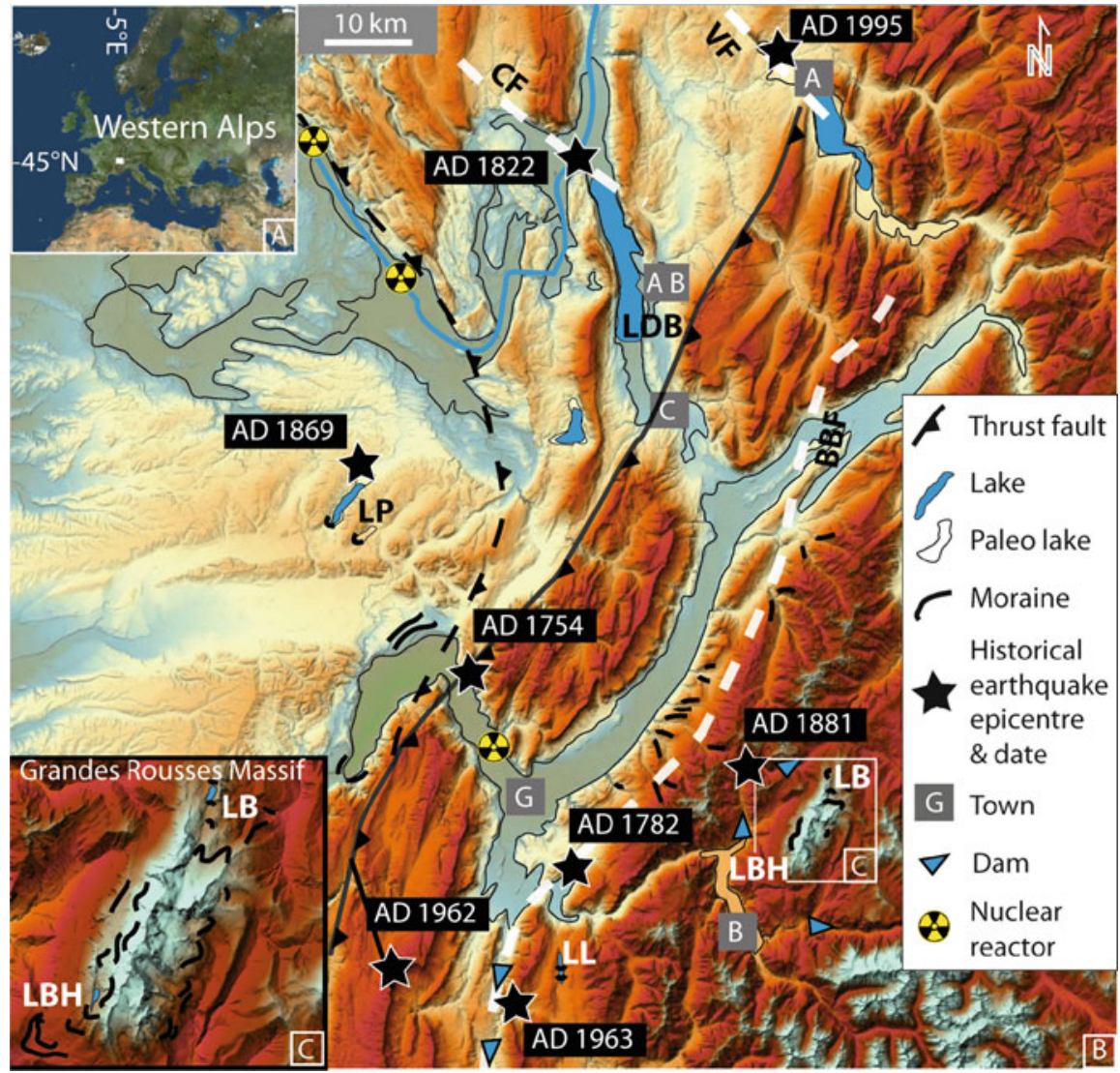

Fig. 34.1 General location of the study area (a) and geomorphological settings (b and $\mathbf{c}$ ) of investigated lakes in the western Alps ( $L P$ Lake Paladru, $L D B$ Lake Le Bourget, $L B H$ Lake Blanc Huez), the main paleo lakes, the Rhone River (blue line), outstanding moraine ridges and historical earthquake epicentres (black stars). The location of major regional thrusts and the active strike slip Belledonne Border Fault $(B B F)$, Culoz Fault $(C F)$ and Vuache Fault $(V F)$ are also illustrated. Lakes Bramant $(L B)$ and Laffrey $(L L)$ together with regional cities $(G$ Grenoble, $C$ Chambéry, $A B$ Aix-les-Bains, $A$ Annecy and $B$ Bourg d'Oisans), nuclear reactors and hydroelectricity dams are also located 
of seismic wave amplification in lacustrine deposits within valleys (site effect) or in mountain ranges (topographic effect). In order to better understand the occurrence of these natural hazards, it is necessary to extend the current earthquake record, based on instrumental and historical data, back in time. It has been demonstrated that lake deposits are natural earthquake archives. Lacustrine sedimentation is highly sensitive to regional earthquake activity and exposed to subaquatic slope failures, violent waves and seiche effects (Siegenthaler et al. 1987; Chapron et al. 1999; Hilbe and Anselmetti 2014). In the present paper, we use highresolution seismic profiling and well-dated sediment cores to report regional, coeval Holocene mass-wasting deposits (MWDs) in three lakes, at variable altitudes. We discuss their sensitivities to earthquake activity according to their setting and dominating sedimentary processes.

Lake Le Bourget is a long and narrow over-deepened basin of glacial origin located at $231.5 \mathrm{~m}$ above sea level (a.s.l.) located in a syncline at the inner Jura mountains along active strike-slip transfer faults (Fig. 34.1). The area was struck by the largest historical earthquake of the Western Alps: the AD 1822 Chautagne event had a Medvedev-Sponheuer-Kamik (MSK) intensity VII-VIII and a 5.5-6 equivalent magnitude (Chapron et al. 1999). Lake Le Bourget was part of a larger Rhone valley lake system but progradation of the Rhone fan delta in the Chautagne area isolated the present lake from its main tributary around 10,060 \pm 150 cal BP (Arnaud et al. 2012). Today, the lake has two active delta systems build by its present-day tributaries; the Leysse and the Sierroz rivers (Fig. 34.2). Its basin-fill has been intensively studied over the last decades (Arnaud et al. 2012). For this study we used high-resolution (vertical resolution $<1 \mathrm{~m}$ ) bathymetry (Ledoux et al. 2010) and unpublished $12 \mathrm{kHz}$ Chirp subbottom profiles. The recent basin-fill consists of a major slope failure deposit (the Hautecombe Disturbed Unit, HDU), which extends over the entire northern part of Lake Le Bourget (Chapron et al. 2005; Debret et al. 2010). The HDU was dated to the Early Holocene ( $9550 \pm 150 \mathrm{cal}$ BP). After this event, Holocene lacustrine sedimentation is dominated by autochthonous carbonates and formed an up to $15 \mathrm{~m}$ thick lacustrine drape.

Lake Paladru is a small basin of glacial origin in the alpine foreland (Fig. 34.1) damned at $492 \mathrm{~m}$ a.s.l. by Pleistocene frontal moraines. It has two tributaries (Surand and Courbon rivers) that developed small deltas. Its basin-fill is exclusively documented by $12 \mathrm{kHz}$ chirp profiling, a piston core (PAL09) and seven short gravity cores (Fig. 34.3). A detailed correlation of the cores is based on the identification of distinct lithological facies, aided by samples analysis with a Scanning Electron Microscope (SEM) and laser grain-size measurements on the upper part of PAL09. Since ca. 14,000 years cal BP, sedimentation of autochthonous carbonates formed a lacustrine drape of up to $5 \mathrm{~m}$ thick (Simonneau et al. 2013).

Lake Blanc Huez is a small narrow proglacial lake located at $2543 \mathrm{~m}$ a.s.l. at the south western side of the Grandes Rousses Massif (Fig. 34.1). As further detailed in Chapron et al. (2007) and Simonneau et al. (2014), this lake deglaciated before ca. 9700 cal BP. Glacier activity within its catchment area $\left(3.2 \mathrm{~km}^{2}\right)$ was very limited from the Early to the Mid Holocene but increased since the onset of the 
a
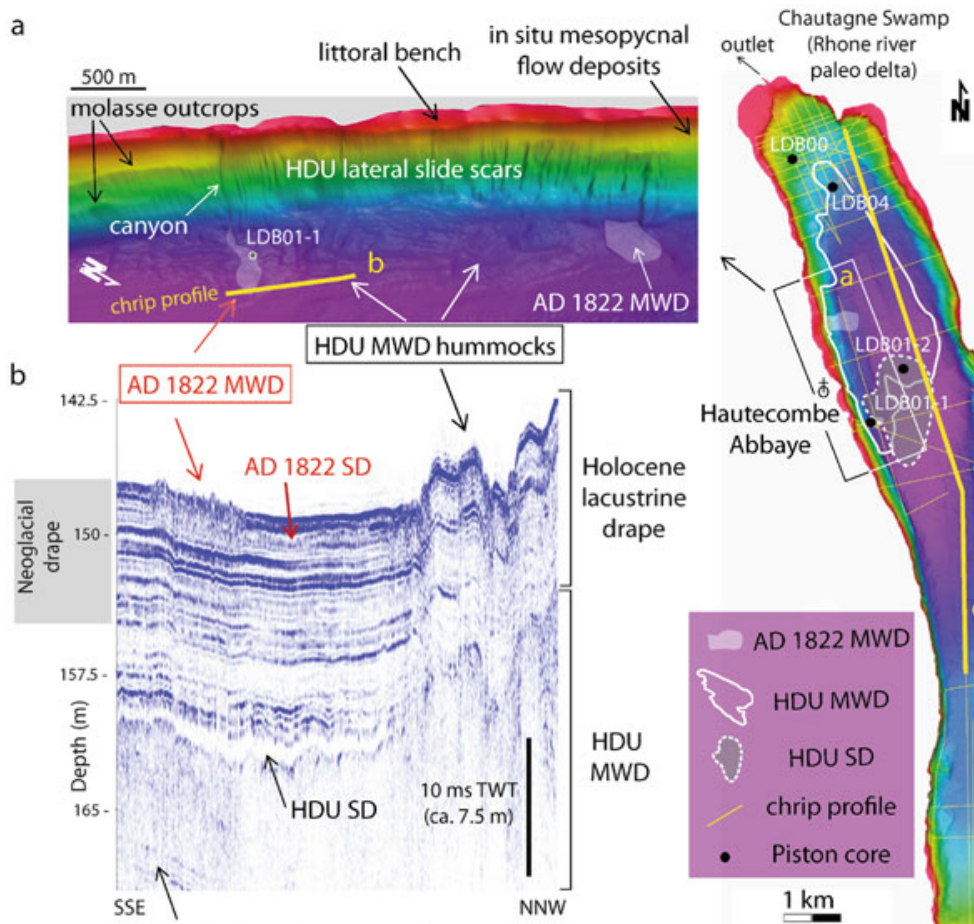

Bathymetry
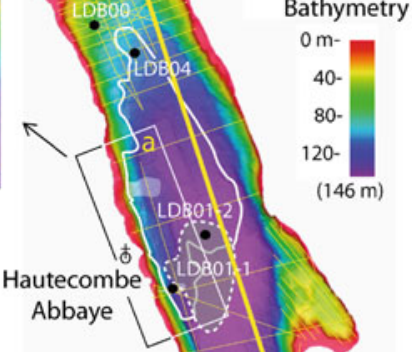

Late Glacial in situ hyperpycnal flow deposits

C

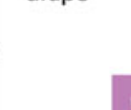

HDU

MWD
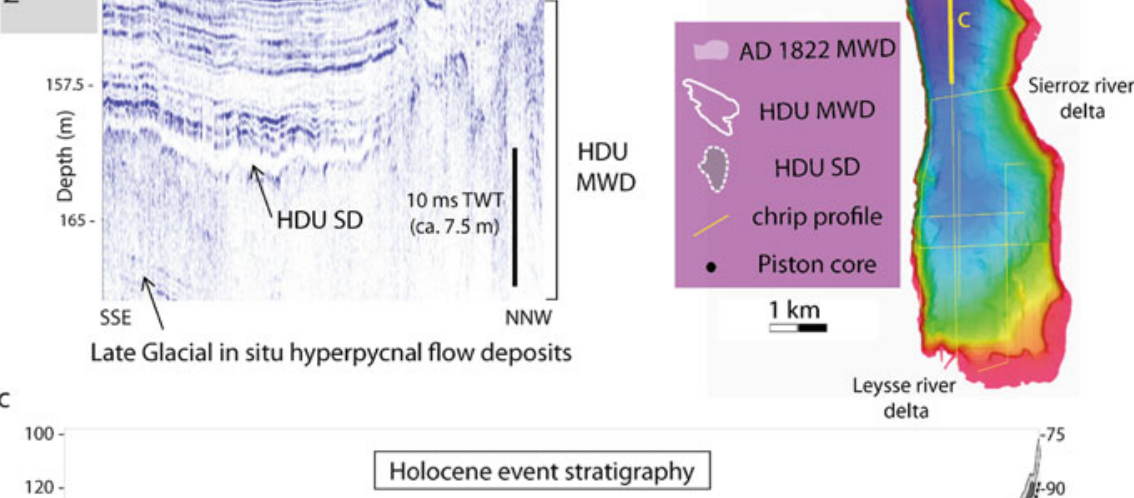

delta

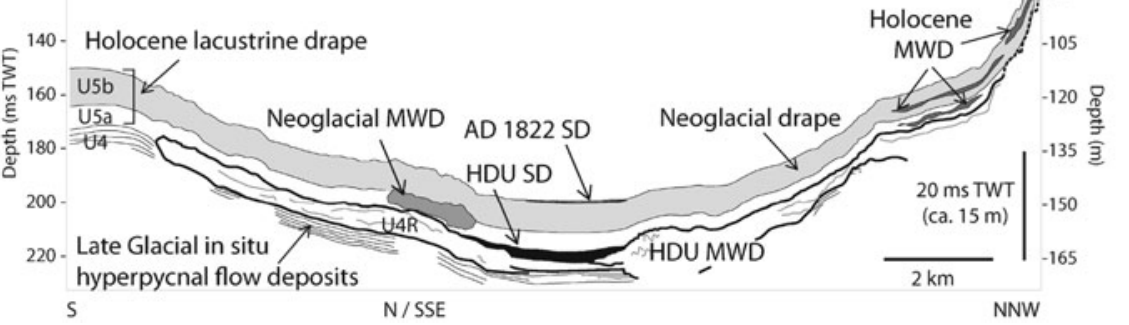

Fig. 34.2 Illustration of Lake Le Bourget geomorphology and stratigraphic characteristics of earthquake-induced mass wasting deposits $(M W D)$ and seiche deposits $(S D)$ developed in $\mathrm{AD}$ 1822, at the onset of the Neoglacial period and in the early Holocene (HDU Hautecombe Disturbed Unit) according to $12 \mathrm{kHz}$ Chirp sub-bottom profiles (yellow lines), multibeam bathymetric data and sediment cores (black dots). A zoom of the bathymetric map (a) localize chrip profile given in (b) and illustrate the main slide scars and MWDs related to the AD 1822 and the HDU events. Chirp profile (b) illustrates the acoustic facies of the lacustrine drape, MWDs and SDs discussed in the text. The interpretation of a chirp profile along the main basin (c) is locating the Neoglacial MWD and synthetizing the Holocene event stratigraphy based on seismic and core data 


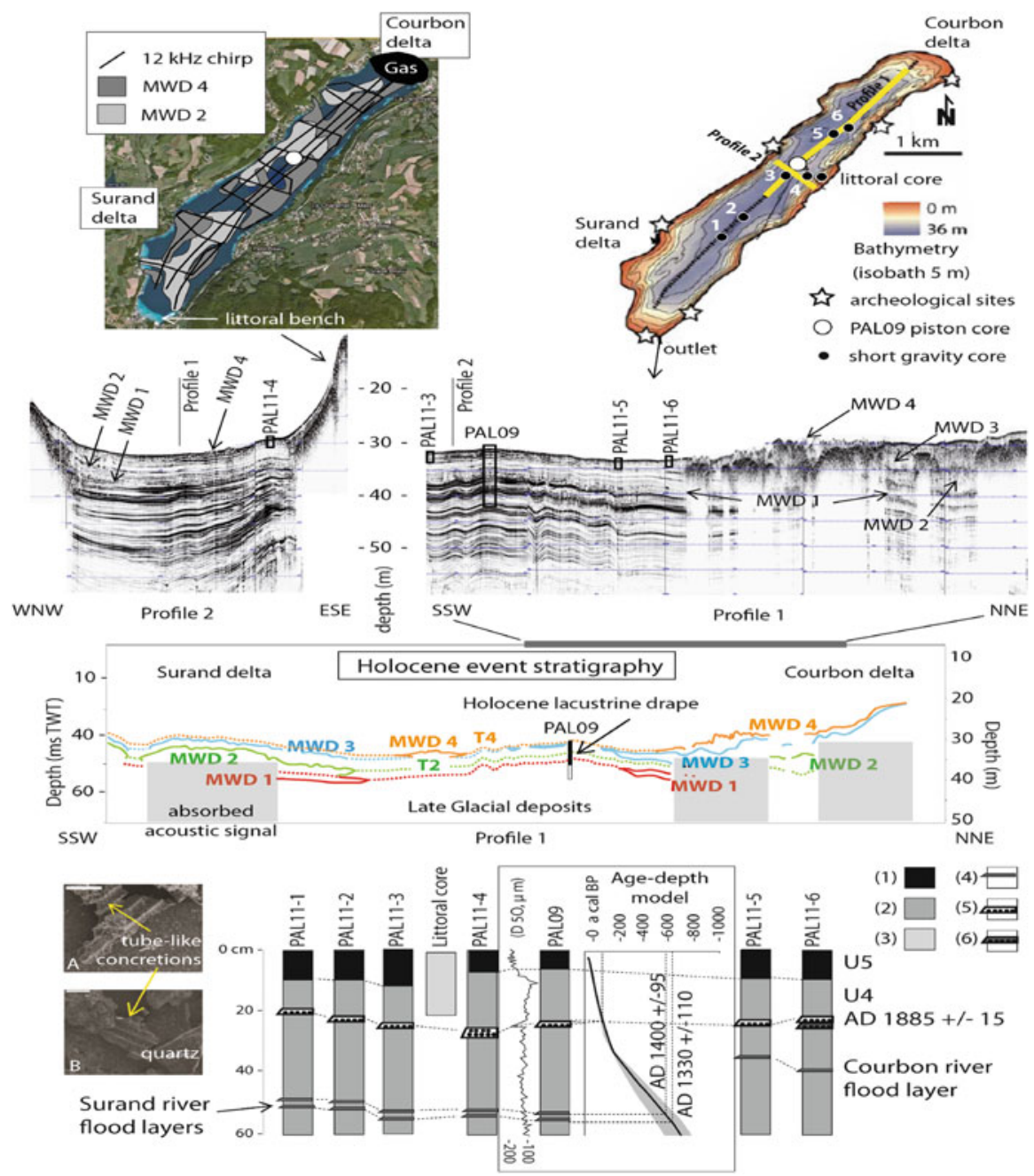

Fig. 34.3 Illustration of Lake Paladru geomorphology and stratigraphic characteristics of mass wasting deposits (MWD) and turbidites (T) according to $12 \mathrm{kHz}$ Chirp sub-bottom profiles (black lines) and well-dated sediment cores (dots) lithologies as detailed in the text and in the lower panel: organic rich lacustrine marls (1); lacustrine marls (2); littoral marls rich in carbonate concretions (3); tributary flood layer (4); carbonated turbidite (5) and minerogenic turbidite (6). Up to four generations of slope instabilities are identified and dated based on seismic stratigraphy, together with PAL09 age-depth model, grain size measurements and scanning electron microscopy images (white bar $=100 \mu \mathrm{m})$ from selected sediment samples in the littoral gravity core $(\mathbf{a})$ and PAL09 piston core (b)

Neoglacial period (ca. 5400 cal BP), which favored the construction of a steep prodelta in the northern part of the lake.

Historical sedimentary events (SEs) associated with MWD's or turbidites in the central basin were dated to AD 1963 (SE11), 1881 (SE10) and either AD 1782 or 
Table 34.1 Records of historical and Holocene earthquakes in lakes Le Bourget (LDB), Paladru (LP), Blanc Huez (LBH), Bramant (LB) and Laffrey (LL) reported in this study and in (1) Simonneau et al. (2014), (2) Guyard et al. (2007), and (3) Nomade et al. (2005) by Mass Wasting Deposits $(M W D s)$ ranging from slump $(S)$, debris flow $(D F)$, turibidite $(T)$ and seiche deposit $(S D)$

\begin{tabular}{l|l|l|l|l|l}
\hline LDB & LP & LBH (1) & $\begin{array}{l}\text { LB } \\
(2)\end{array}$ & LL (3) & $\begin{array}{l}\text { Historical } \\
\text { earthquake }\end{array}$ \\
\hline & & SE11 (S) & & DF1/DF2 & AD 1962/63 \\
\hline & MWD4 + T4 ? & SE10 (T) & S & DF4 & AD 1881 \\
\hline & MWD4 + T4 & & & DF4 ? & AD 1869 \\
\hline & & SE9(T) & T & & AD 1822 \\
\hline & MWD3 & & & DF5 & AD 1782 \\
\hline & $($ AD 1,660+/-100 & & & DF6 & AD 1754 \\
\hline & & & & & \\
\hline Neogl.MWD & MWD2+T2 & SE4 & & & $\begin{array}{l}\text { Holocene } \\
\text { earthquake }\end{array}$ \\
\hline H,020+/-200) & $(5,190+/-50)$ & $(5,375+/-175)$ & & & ca. 5,200 cal BP \\
\hline HDU MWD+SD & MWD1 & SE1 & & & \\
\hline$(9,550+/-150)$ & $(9,010+/-600)$ & $(9,680+/-140)$ & & & ca. 9,550 cal BP \\
\hline
\end{tabular}

1822 (SE9). They highlight the sensitivity of this lake to regional historical earthquakes (Fig. 34.1 and Table 34.1). Similar Holocene sedimentary events (Simonneau et al. 2014) are dated to $5375 \pm 175 \mathrm{cal} \mathrm{BP}$ (SE4) and $9680 \pm 140 \mathrm{cal}$ BP (SE1).

\subsection{Results}

In Lake Le Bourget, multiple MWDs coeval to the impact of the AD 1822 Chautagne earthquake remolded mesopycnal distal flood deposits from the Rhone River and carbonate sandy silt from the littoral bench down to $130 \mathrm{~m}$ water depths (Chapron et al. 1999, 2005). A canyon and a related carbonate MWD at its downslope termination are clearly imaged on bathymetry and $12 \mathrm{kHz}$ Chirp profiles (Fig. 34.2). The MWD has been sampled in core LDB01-1 and interpreted as a slump deposit (Arnaud et al. 2005). This slump is laterally evolving into a pluridecimetric seiche deposit. The seiche deposit, located in the deepest part of the central basin, is characterized by a transparent acoustic facies on Chirp data (Fig. 34.2) and corresponds to a fine-grained homogeneous sedimentary facies in gravity cores (Chapron et al. 1999, 2005; Jenny et al. 2014). The Holocene lacustrine drape in Lake Le Bourget is subdivided in two acoustic facies (Fig. 34.2): a transparent basal facies (U5a) matching Early Holocene lacustrine marls in piston cores (Arnaud et al. 2005, 2012; Debret et al. 2010); and a upper 
stratified facies (U5b) characterized by several high-amplitude and continuous reflections resulting from more frequent Rhone River flood events since the Neoglacial period. The base of the so-called "Neoglacial drape" is thus a key chrono-stratigraphic marker horizon on seismic profiles and allows dating a MWD to ca. $5000 \pm 200$ cal BP using LDB01-1, LDB01-2 and LDB04 piston cores (Fig. 34.2) age-depth models (Chapron et al. 2005; Arnaud et al. 2012). This MWD is a chaotic to transparent lens-shaped body at the transition from facies U5a to U5b, located at the eastern edge the eastern central basin. The Early Holocene HDU event forms a MWD consisting in a decametric chaotic to transparent lens-shaped body with a hummocky topography. It is evolving southward into a plurimetric turbidite characterized by a transparent acoustic facies ponded in the deepest part of the basin. The paleo-topography of associated MWDs at the foot of northern and western slopes is draped by Holocene sediments and still clearly visible on bathymetric data (Fig. 34.2).

In Lake Paladru, up to four generations of MWDs are identified within its lacustrine drape on $12 \mathrm{kHz}$ profiles (Fig. 34.3). They are stacked in the front of Surand and Courbon deltas and developing lens-shaped bodies with chaotic to transparent facies that are locally absorbing the acoustic signal. Only the upper (MWD4) and the intermediate (MWD2) slope failure events can be clearly mapped. These two events consist in coeval slope failures both impacting deltaic environments and littoral benches. MWD4 is laterally associated with an outstanding light-colored sandy turbidite, rich in carbonate concretions (T4) dated to AD $1885 \pm 15$ and identified on a transect of six cores across the basin. In core PAL11-6, this key horizon is, in addition, covering a dark colored minerogenic sandy turbidite. The age of MWD3 is estimated to $290 \pm 100$ cal BP (AD $1660 \pm 100$ ) based on seismic stratigraphy (i.e. tracing across the basin the low amplitude but continuous reflection that drape MWD3) and on PAL09 age-depth model (Simonneau et al. 2013). Dating uncertainty is derived by assuming a vertical resolution on seismic profiles of $7 \mathrm{~cm}$ and considering a mean sedimentation rate of $0.7 \mathrm{~mm} /$ year on PAL09 at the related core depth. The age of MWD2 is similarly based on seismic stratigraphy and is further supported by the identification of a striking light colored sandy layer (T2) at $275 \mathrm{~cm}$ in core PAL09 precisely dated to $5190 \pm 50 \mathrm{cal}$ BP. Finally, the age of MWD1 is estimated to $9010 \pm 600 \mathrm{cal}$ BP by seismic stratigraphy, PAL09 age-depth model and taking into consideration the vertical resolution of seismic data with a mean sedimentation rate of $0.3 \mathrm{~mm} / \mathrm{year}$.

\subsection{Discussion}

The sedimentary record of historical earthquakes in the area (Fig. 34.1 and Table 34.1) documented by Nomade et al. (2005), Guyard et al. (2007), and Simonneau et al. (2014) are summarized in this study. Due to dating uncertainties, MWD4 and MWD3 in Lake Paladru may be, contemporary to the AD 
1881 Allemond and the AD 1754 Voreppe events, respectively. But MWD4 may also result from the combination of a locally documented earthquake (the AD 1869 Charavine event) and an abrupt lake level change in AD 1870 described by Dutey Grinet (1873) and reported in Colardelle and Verdel (1993). This last event triggered numerous slope failures along its littoral benches in AD 1870. This interpretation is further supported by the identification on SEM images of similar tube-like carbonate concretions both in T4 and in the littoral core (Fig. 34.3), that are typical from the edge of a littoral bench (Magny et al. 2008). The siliciclastic turbidite deposited just below T4 in PAL11-6 may thus be earthquake triggered, while T4 and several MWDs may result from the following lake-level changes in AD 1870. A similar combination of ground motion and lake-level changes may also explain the development of MWD2 and T2 at ca. 5200 cal BP. The same regional earthquake may have triggered SE4 in Lake Blanc Huez and the Neoglacial MWD in Lake Le Bourget. Both of these slope failure events were likely facilitated by changes in sedimentation modes due to enhanced glacier activities in their catchment areas (Simonneau et al. 2014) and clastic supplies in deltaic areas. Similarly, a regional earthquake at ca. 9550 cal BP occurring during the Boreal period that was associated with important environmental changes (in vegetation, glacier activity and lake-level) in Western Europe (Magny et al. 2014), may have triggered MWD1 in Lake Paladru, SE1 in Lake Blanc Huez and the HDU in Lake Le Bourget. The larger amplitude of the coeval HDU event is here clearly resulting from its isolation from the Rhone River and a drastic drop in siliciclastic sediment supply. These observations suggest that the sensitivities of lake sediments to earthquakes are not only related to the distance and intensity of earthquakes, but also to the geomorphology and sedimentation patterns in the lakes.

\subsection{Conclusion}

Coeval regional MWDs in lake sediments from the French alpine foreland highlight the impact of historical earthquakes in AD 1822, 1881 and 1962. Similarly, and within radiocarbon and seismic stratigraphic dating uncertainties, Holocene regional earthquakes potentially triggered coeval MWDs in lakes Le Bourget, Paladru and Blanc Huez at ca. 5200 and 9550 cal BP. This study suggest that lakes sensitivity to ground motion was enhanced by changes in sedimentation modes following environmental changes associated with the Little Ice Age, Neoglacial and Boreal periods.

Acknowledgments The authors wish to thank G. Vargas and P. Van Rensbergen for their constructive reviews and G. Lamarche for his contribution to the improvement of this manuscript. 


\section{References}

Arnaud F, Revel M, Chapron E et al (2005) 7200 years of Rhone river flooding activity in Lake Le Bourget, France: a high-resolution sediment record of NW Alps hydrology. The Holocene 15:420-428

Arnaud F, Révillon S, Debret M et al (2012) Lake Bourget regional erosion patterns reconstruction reveals Holocene NW European Alps soil evolution and paleohydrology. Quat Sci Rev 51:81-92

Chapron E, Beck C, Pourchet M, Deconinck J-F (1999) 1822 earthquake-triggered homogenite in Lake Le Bouregt (NW Alps). Terra Nova 11:86-92

Chapron E, Arnaud F, Noël H et al (2005) Rhone River flood deposits in Lake Le Bourget: a proxy for Holocene environmental changes in the NW Alps, France. Boreas 34:404-416

Chapron E, Faïn X, Magand O et al (2007) Reconstructing recent environmental changes from proglacial lake sediments in the Western Alps (Lake Blanc Huez, 2543 m a.s.l., Grandes Rousses Massif, France). Palaeogeogr Palaeoclimatol Palaeoecol 252:586-600

Colardelle M, Verdel E (1993) Les habitats du lac de Paladru dans leur environnement: la formation d'un terroir au XIe siècle. Documents d'archéologie française, Edition de la Maison des Sciences de l'Homme

Debret M, Chapron E, Desmet M et al (2010) North western Alps Holocene paleohydrology recorded by flooding activity in Lake Le Bourget, France. Quat Sci Rev 29:2185-2200

Guyard H, Chapron E, St-Onge G et al (2007), High-altitude varve records of abrupt environmental changes and mining activity over the last 4000 years in the Western French Alps (Lake Bramant, Grandes Rousses Massif). Quat Sci Rev 26(19):2644-2660

Hilbe M, Anselmetti F (2014) Mass movement-induced tsunami hazard on perialpine Lake Lucerne (Switzerland): scenarios and numerical experiments. Pure Appl Geophys. doi:10.1007/s00024-014-0907-7

Jenny J-P, Wilhelm B, Arnaud F et al (2014) A 4D sedimentological approach to reconstructing the flood frequency and intensity of the Rhone River (Lake Bourget, NW European Alps). J Paleolimnol 51:469-483

Ledoux G, Lajeunesse P, Chapron E, St-Onge G (2010) Multibeam bathymetry investigations of mass movements in Lake Le Bourget (NW Alps, France) using a portable platform. In: Mosher DC et al (eds) Submarine mass movements and their consequences, advances in natural and technological hazards research. Springer, The Netherdlands, vol 28, pp 423-433

Magny M, Peyron O, Gauthier E et al (2008) Quantitative reconstruction of climatic variations during the Bronze and early Iron ages based on pollen and lake-level data in the NW Alps France. Quat Int. doi:10.1016/j.quaint.2008.03.011

Magny M, Combourieu-Nebout N, de Beaulieu J-L et al (2014) North-south palaeohydrological contrast in the central Mediterranean during the Holocene: tentative synthesis and working hypotheses. Clim Past 9:2043-2071

Nomade J, Chapron E, Desmet M et al (2005) Reconstructing historical seismicity from lake sediments (Lake Laffrey, Western Alps, France). Terra Nova 17:350-357

Siegenthaler C, Finger W, Kelts K, Wanf W (1987) Earthquake and seiche deposits in Lake Lucerne, Switzerland. Eclogae Geol Helv 80:241-260

Simonneau A, Doyen E, Chapron E et al (2013) Holocene land-use evolution and associated soil erosion in the French Prealps inferred from Lake Paladru sediments and archaeological evidences. J Archaeol Sci 40:1636-1645

Simonneau A, Chapron E, Garçon M et al (2014) Tracking Holocene glacial and high-altitude alpine environments fluctuations from minerogenic and organic markers in proglacial lake sediments (Lake Blanc Huez, Western French Alps). Quat Sci Rev 89:27-43

Thouvenot F, Fréchet J, Jenatton L, Gamond J-F (2003) The Belledonne border fault: identification of an active seismic strike-slip fault in the western Alps. Geophys J Int 155:174-192

Van Rensbergen P, de Batist M, Beck C, Chapron E (1999) High-resolution seismic stratigraphy of glacial to interglacial fill of a deep glacigenic lake: Lake Le Bourget, Northwestern Alps, France. Sediment Geol 128:99-129 